\title{
Journal of Management, Marketing and Logistics

\section{THE INFLUENCE OF CITY IMAGE ON THE UNIVERSITY SELECTIONS OF STUDENTS STUDYING IN THE DEPARTMENT OF MARKETING}

\author{
DOI: 10.17261/Pressacademia.2018.810 \\ JMML- V.5-ISS.1-2018(8)-p.87-95
}

\section{Ahmet Uyar}

Afyon Kocatepe University, Afyon, Turkey.

ahmetuyar@aku.edu.tr, ORCID: 0000-0002-7481-4045

To cite this document

Uyar, A. (2018). The influence of city image on the university preferences of students studying in the department of marketing. Journal of

Management, Marketing and Logistics (JMML), V.5(1), p.87-95.

Permemant link to this document: http://doi.org/10.17261/Pressacademia.2018.810

Copyright: Published by PressAcademia and limited licenced re-use rights only.

\begin{abstract}
Purpose - This study analyses the influence of city image on university students. The question "How are students influenced by city image when they are making their school selections?" is the main topic of the study.

Methodology - The questionnaire form was created after a literature search and subjected to a pilot scheme after it was revised based on the opinions of specialist academicians. When determining research questions, studies by Demirel (2014) and Özdemir and Karaca (2009) were drawn upon, and its validity and reliability were tested by administering 40 pilot questionnaires before putting it into its final form. Data obtained were subjected to an SPSS analysis, and the influence of city image on university selections was analysed with the help of regression and correlation analyses and comparative tables.

Findings- In this study, it is concluded that students primarily choose those schools which are in a close distance to where they live. As a result of increasing competition, many schools have begun to acquire students from their own region. Factors like natural and historical attractions and social environment also shape the selections of students. When making these selections, students consult with those around them such as their friends, and thus they obtain the first information about a certain school from them.

Conclusion- It is seen when the findings of the study were assessed in general that students make their university selections primarily based on the city in which universities are located. Proximity of a school to where they live and factors shaping the image of a city such as sociality and cultural/natural richness also become influential in this selection. Those students who act according to city images become happier during their educational lives, and their level of satisfaction with their university tends to increase.
\end{abstract}

Keywords: City image, university students, university selection, consumer preferences, city development JEL Codes: M30, M31, M39

\section{INTRODUCTION}

In Turkey, millions of students take the university entrance exam each year. Therefore, the contribution that students make to the city of their university education by their socioeconomic influences bring about important results.

As of 2015 , the number of students studying in undergraduate departments is 3,628,800. A total of 2,013,762 students study in associate degree programs including open education and distance education, 342,101 students study in master degree programs and 78,223 students in doctorate programs. The total number of students studying open education is $2,803,064$, while 59,282 students study in distance education. The number of students studying in state universities is 5,615,293. (http://www.sinavtakvim.com)

University exams that concern millions of students raise the question "the schools in which city will students prefer?". Opening of many universities especially in recent years has increased the demand for certain departments. Thousands of unfilled quotas remain each year. In 2016, the number of unused quotas remaining after the central placement in universities was 60,147 (http://www.haberturk.com). 
As of 2017, there are 183 universities in Turkey. Of these, 118 are state universities while 65 of them are foundation universities. As of 2015, the total number of students is 6.062 .886 . Of these, 3.276 .658 are male while 2.786 .228 are female (https://tr.wikipedia.org).

Especially the unfilled quotas in many Anatolian universities and in some private schools are striking. In some universities, associate and undergraduate programs are removed due to a lack of demand. Therefore, the question of the criteria that students consider when they are making their university preferences gains importance. Universities need to act according to these preference variables.

The current study is based on the assumption that students determine their university according to city images. Rather than factors such as the presence of certain academicians, educational quality and social opportunities of a school, students make their university preferences according to the city in which a university is located. Therefore, city image should be carefully examined by local governors.

\section{LITERATURE REVIEW}

There are some Turkish and foreign studies about the criteria that students consider when they are making their university preferences. According to Drives and Michael (2006) and Shah and Nair (2010), students take the following factors into consideration when they make their university preferences;

- Amount of scholarship that a school will offer to a student and the total amount of school fee that a student has to pay,

- Information that students obtain from their friends and other people around them,

- Safety of the campus area,

- Expectations regarding their academic careers,

- Opinions of the families of students,

- Expectations of university lecturers.

In addition to these factors, a city's image and location, its characteristics and level of development also influence the university preference of students. Those cities which make a positive impression in terms of image attract the audience which is influenced by it, and show development in areas like tourism and education.

An image, which is utilised in all marketable products and processes, is a picture, impression or map that forms in human mind as regards any event, object, person, business, country or city (Bakan, 2008: 293). An image relating to a certain destination is classified into two as basic image and special image. A basic image is such factors as places to be seen, recreation, infrastructure adequacy, urban cost, access network structure, and historical, political and cultural characteristics. A special image on the other hand is a relative image that changes from person to person. A special image is a type of image which emerges in connection with a basic image and involves the differences among consumers arising based on perception (Özdemir, Karaca, 2009:118). When forming a city image, therefore, it is necessary to try creating a special image that will have a positive influence on people. A city image is a person's group of beliefs that consists of that person's thoughts and opinions about a city. The totality of psychological characteristics impressed on the mind of an audience as regards a city can also be called city image (Gecikli, 2012: 5).

The goal of city image development involves the idea of attracting people's attention to it and creating a positive image about it. But the marketing of cities is not as easy as that of branded products or other commercial goods (Dumbraveanu, 2010: 54). Therefore, the aim in the context of a city image is to increase the awareness of a certain city, to be recognised nationally and internationally.

There is a communication between a city and the people who live in or visit that city. This communication gives people a perception about the image of the city (Uçkaç, 2006: 4). When a city is evaluated from an individual perspective, the person's past, social status, environmental experience, worldview, and lifestyle can be important factors. As for the evaluation of a city based on a group identity, what gains importance is the common values and social roles in the society in which a person lives and whether or not these values are compatible with environmental quality. Rather than persons, the socio-cultural characteristics of the community in which the person lives play an active role in this second type of evaluation. (Ünlü, 1991: 328). Thus, differences of opinions in the evaluation of a particular region are due to the variety of personal characteristics.

What is understood from the concept of city image is the appearance and lifestyle of that city. The streets, avenues, parks and gardens, sculptures and libraries of the city, its places that people collectively use, the clothing and behaviors of its people, and its architectural structure change the feelings and thoughts we have about that city. Space, time, and 
movement determine the boundaries of the city and impose a meaning on all living/ inanimate beings and things (Sevindi, 2003: 101).

In recent years, local governors, city planners and urban decision-makers have begun to take important initiatives to promote their cities and strengthen their image globally. These people believe that the general image of a city is an important factor in the decision making process for various target groups (Avraham, 2004: 471).

In current times of intense competition, it is necessary to actively get covered in media to improve the image of one's city rather than waiting for a coincidental media coverage (Paşal Taşoğlu, 2012: 70). Kotler stated that city images in the minds of people may be positive, negative or mixed. There are very few cities with a totally positive or negative image. Many cities have a mixed or weak image. Cities with a negative image have obstacles in front of their socio-cultural development. People living in that city tend to have negative thoughts about it (Yuan and Chong, 2007: 257).

The current appearance of a city creates our first impressions of that city. The images occurring in the mind of a person who lives in or visits the city are influential in the formation of an image of that city in their mind (Engez, 2007: 47).

There are many factors that influence city images. According to Beerli and Martin (2004) these factors are as listed below:

Table 1: Factors Influencing City Images

\begin{tabular}{|l|l|}
\hline Natural resources & $\begin{array}{l}\text { Weather (temperatures, humidity, sun, overcast, etc.), Beaches (sands, nature of sea, quality } \\
\text { of beaches, rocky areas etc.), Richness of rural areas (protected natural resources, lakes, } \\
\text { mountains, sea, etc.), Diversity and uniqueness of fauna and flora. }\end{array}$ \\
\hline Infrastructure & $\begin{array}{l}\text { Advanced and quality roads, airports and ports, Private and public transport, Status of health } \\
\text { services, Status of communication services, Status of commercial infrastructures, Prevalence } \\
\text { of modern buildings. }\end{array}$ \\
\hline Tourism Resources & $\begin{array}{l}\text { Quality of hotels and accommodation (number of beds, facilities, etc.) Existence of } \\
\text { restaurants, bars, disco clubs, cafes, etc. Number and quality of tourism centres, accessibility } \\
\text { of destinations. }\end{array}$ \\
\hline $\begin{array}{l}\text { Entertainment } \\
\text { Resources }\end{array}$ & $\begin{array}{l}\text { Thematic parks, Entertainment and sports activities (golf, fishing, hunting, skiing, diving, } \\
\text { etc.), Water parks, zoos, adventure activities, shopping. }\end{array}$ \\
\hline $\begin{array}{l}\text { Cultural, historic and } \\
\text { artistic opportunities }\end{array}$ & $\begin{array}{l}\text { Abundance of historical sites, musical and artistic activities. Centres of religion, folklore, } \\
\text { handicrafts and gastronomy. }\end{array}$ \\
\hline $\begin{array}{l}\text { Political and Economic } \\
\text { Factors }\end{array}$ & $\begin{array}{l}\text { Political stability, Political trends, Economic development, Security (crime rate, terrorist } \\
\text { attacks), prices of products and services. }\end{array}$ \\
\hline Environment & $\begin{array}{l}\text { Landscape beauty, Attractiveness of cities and districts, Cleanliness, Crowd population, Air } \\
\text { and noise pollution, Traffic congestion. }\end{array}$ \\
\hline Social Factors & $\begin{array}{l}\text { Hospitality and friendliness of local people, Discrimination and poverty, Quality of life, } \\
\text { Language barrier }\end{array}$ \\
\hline Urban Atmosphere & $\begin{array}{l}\text { Luxury, Fashion, Famous places, Family places, Exotic, Mystical, Relaxing, Stressful, Fun- } \\
\text { pleasant; Existence of Pleasant, Boring, Attractive or interesting places. }\end{array}$ \\
\hline
\end{tabular}

In addition to the resources of a city, there are things that should be done in order for it to be a marketable product and develop. These are as follows (Rainisto, 2003: 13):

1) A city should provide fundamental services and develop its infrastructure facilities for the satisfaction of its citizens, business circles, investors and visitors.

2) It should create attractive resources to maintain existing business activities, receive general public support, and attract new investors, entrepreneurs and tourists.

3) It should improve its advertising activities and its image, and believe in the benefits of these.

4) It should receive support from civil society, leaders, and company representatives.

A favourable city image increases the interest that students take in a city and influences their university preferences. And cities attracting more students show more development (Demirel, 2014: 233). University students make a specially significant influence on the economic and social development of a city. Besides, universities and their stakeholders make a contribution to a city in many topics such as creation of a qualified workforce, development of new fields of business, interaction with different cultures, development of employment and commerce. 


\section{DATA AND METHODOLOGY}

For the purpose of the research, numeric data collected by the method of face-to-face questionnaire were analysed using the SPSS 18 software package. The population of the research was 4364 students studying in the marketing departments of different universities. As it was not possible to reach all the population, the sampling method was embraced.

The "Convenience Sampling Method" was used in the research. When determining the sample size, the sampling formula which is utilised for quantitative variables and considered for unlimited populations or those with an unknown volume was used (Özdamar, 1999: 260).

The questionnaire form was created after a literature search and subjected to a pilot scheme after it was revised based on the opinions of specialist academicians. When determining research questions, studies by Demirel (2014) and Özdemir and Karaca (2009) were drawn upon, and its validity and reliability were tested by administering 40 pilot questionnaires before putting it into its final form.

The questionnaire form, which was drawn up according to the 5-Point Likert Scale, was administered to associate degree students studying in 10 different colleges in Turkey between 1 January and 15 February 2017. The research was expanded to involve students from another 5 colleges between 20 May and 10 June 2017.

The questionnaire form consists of four parts.

In the first part, the participants were asked questions about the importance of city image in their university selections.

In the second part, they were asked a question about the sources from which they obtained information about their school before choosing it.

In the third part, students were asked to rank their reasons for choosing the university that they currently attend to.

In the last part, questions regarding the demographic data of participants were asked.

In the research, a total of 600 questionnaire forms were obtained taking into consideration that there might be questionnaire forms which might be excluded from analysis due to such reasons as level of reliability, margin of error, deficient or erroneous coding, etc. and also considering the researcher's opportunities of reaching the target audience. A total of 500 questionnaire forms were included in the analysis by excluding 100 questionnaire forms due to deficient or erroneous coding.

The research data collected by the questionnaire method were described by calculating their frequency-percentage distributions, arithmetic means and standard deviations. Reliability of the study was established through Cronbach's Alpha Analysis. The factors which are influential in university selection were presented with the mean and standard deviation values of the influence of city image on university selection. The relationship between the school district and student satisfaction was shown by regression analysis, whereas the relationship between city image and student satisfaction was shown by correlation analysis. In this way, it was studied how the place where students live influences the satisfaction they get from their school. The "t-test" was used for unrelated measurements in comparing the participants' views on the topic and their demographic characteristics.

\section{FINDINGS AND DISCUSSIONS}

\section{Validity and Reliability Analysis}

In the reliability analysis, the alpha coefficient, which is calculated by the method of internal consistency, was taken into consideration. The alpha coefficient is expressed as the weighted standard mean change, which is obtained by proportioning the sum of variances of the k expression in the scale to the general variance. The alpha coefficient is assessed according to the below ranking when calculating the reliability of the scale (Özdamar, 1999: 513-522).

$0.00 \leq \alpha<0.40$ : The scale is not reliable,

$0.40 \leq \alpha<0.60$ : The scale has low reliability,

$0.60 \leq \alpha<0.80$ : The scale is reliable,

$0.80 \leq \alpha<1.00$ : The scale has high reliability 
Table 2: Cronbach's Alpha Analysis

\begin{tabular}{|c|c|}
\hline Cronbach's Alpha & N of Items \\
\hline .760 & 18 \\
\hline
\end{tabular}

According to the results of the reliability analysis, the questionnaire is in the category of reliable questionnaires by a coefficient of 0.76 . Of the questionnaire participants, 272 are male and 228 are female. Forty-four percent of the participants live in a metropolis, $25 \%$ in a city centre and $20 \%$ in a city district. Fifty-four percent of the participants study in a metropolis and $37 \%$ of them study in a city.

\section{Statements of Students about Their University Preferences}

Table 3 shows the reasons for which students preferred the city in which they study. According to the table, the most important factor that influences their preference is the city's proximity to where their family lives. Students make their selections according to ease of access and proximity to their family. Level of development in terms of tourism and presence of natural and historical attractions are other important reasons.

Table 3: The Influence of City Image on University Preference

\begin{tabular}{|c|c|c|c|}
\hline $\begin{array}{l}\text { Statements (my reason for preferring my } \\
\text { current school is because the city is...) }\end{array}$ & $\mathbf{N}$ & Average & Standard Deviation \\
\hline Reliable. & 500 & 3.18 & 1.274 \\
\hline Socially Attractive. & 500 & 3.23 & 1.259 \\
\hline Economically Powerful. & 500 & 2.95 & 1.217 \\
\hline Has a Good Image. & 500 & 3.15 & 1.220 \\
\hline Cheap. & 500 & 2.65 & 1.271 \\
\hline Close to where my family live. & 500 & 3.56 & 1.490 \\
\hline Developed. & 500 & 3.20 & 1.255 \\
\hline Peaceful. & 500 & 3.44 & 1.192 \\
\hline Big. & 500 & 2.92 & 1.252 \\
\hline Developed in Terms of Education. & 500 & 3.23 & 1.141 \\
\hline Has a High Life Quality. & 500 & 3.20 & 1.150 \\
\hline Has Natural and Historical Beauties. & 500 & 3.45 & 1.750 \\
\hline Developed in Terms of Culture/Art. & 500 & 3.22 & 1.204 \\
\hline Has a Powerful Infrastructure. & 500 & 2.91 & 1.229 \\
\hline Developed in Terms of Tourism. & 500 & 3.52 & 6.782 \\
\hline Has Good Municipality Services. & 500 & 2.87 & 1.290 \\
\hline Located in an Easily Accessible Area. & 500 & 3.37 & 1.222 \\
\hline Modernist. & 500 & 3.09 & 1.233 \\
\hline
\end{tabular}

Table 4 includes statements showing the sources from which students gathered information about their current universities before making their school selections. According to the table, students mostly obtain information from their acquaintances. The rate of those who agree with this statement is $40 \%$. Thus, students' friends and others around them provide them with information about universities and shape their selections. And the rate of the students collecting information from Internet sources such as social media and school websites is around $20 \%$.

Table 4: Information Gathered about a School before Making University Selections

\begin{tabular}{|l|c|c|}
\hline Statements & Yes & Percentage \\
\hline $\begin{array}{l}\text { Hearsay (I don't remember where I } \\
\text { heard about it) }\end{array}$ & 49 & 9.8 \\
\hline Media (TV, newspapers, radios, etc.) & 17 & 3.4 \\
\hline $\begin{array}{l}\text { Celebrities (artists, politicians, } \\
\text { sporters, etc.) }\end{array}$ & 6 & 1.2 \\
\hline Written sources (books, brochures, & 20 & 4 \\
\hline
\end{tabular}




\begin{tabular}{|l|c|c|}
\hline journals, etc.) & & 40.8 \\
\hline $\begin{array}{l}\text { Acquaintances (friends and other } \\
\text { acquaintances) }\end{array}$ & 204 & 20.8 \\
\hline $\begin{array}{l}\text { Internet (social media, school } \\
\text { website, etc.) }\end{array}$ & 104 & 6.2 \\
\hline OSYM booklet & 31 & 13.4 \\
\hline Had no information. & 67 & \\
\hline
\end{tabular}

Table 5 lists the reasons for which students preferred their current school. According to the table, the city in which a school is located is a factor that primarily determines the university selections of students. While city is the most important reason of preference for about $37 \%$ of students, the score acquired in the undergraduate placement exam is the second most important factor. When Tables 3 and 4 are taken together, it is seen that city characteristics and image are the most decisive factor in university preferences.

Table 5: Factors Influential in University Selections

\begin{tabular}{|c|c|c|c|}
\hline $\begin{array}{l}\text { Statements (in percentage } \\
\text { expressions, values } \\
\text { following a dot were not } \\
\text { considered.) }\end{array}$ & 1st Row (\%) & 2nd Row (\%) & 3rd Row (\%) \\
\hline $\begin{array}{l}\text { The City in Which the } \\
\text { School Is Located }\end{array}$ & 37.2 & 14.4 & 13.6 \\
\hline $\begin{array}{l}\text { Education Quality of The } \\
\text { School }\end{array}$ & 4.6 & 15.0 & 13 \\
\hline $\begin{array}{l}\text { My Exam Score Was } \\
\text { Sufficient Only for This } \\
\text { School }\end{array}$ & 16.8 & 22 & 16.8 \\
\hline $\begin{array}{l}\text { My Preference Was Based } \\
\text { on Department, Not on } \\
\text { School }\end{array}$ & 12.2 & 11.2 & 8.4 \\
\hline Family Desire/Pressure & 6.8 & 8.8 & 8.8 \\
\hline $\begin{array}{l}\text { Guidance by Prep/High } \\
\text { School Teachers }\end{array}$ & 3.0 & 6.4 & 6.2 \\
\hline $\begin{array}{l}\text { Academicians available in a } \\
\text { School }\end{array}$ & 1.8 & 3.4 & 2.4 \\
\hline $\begin{array}{l}\text { Social Opportunities of a } \\
\text { School }\end{array}$ & 3.6 & 5.4 & 8.0 \\
\hline $\begin{array}{l}\text { The Desire of Getting Away } \\
\text { from the City of Dwelling }\end{array}$ & 10 & 8 & 11.4 \\
\hline None of These & 2.6 & 2.4 & 5.2 \\
\hline
\end{tabular}

Table 6 shows the influence of sex on university preferences. According to the table, when compared with female students, male students acted more based on the guidance of their prep school teachers and considered the academicians available in universities when they made their university selections.

Table 6:. The T-Test Comparing the Influence of City Image in School Selections by Sex Difference

\begin{tabular}{|l|c|c|c|}
\hline $\begin{array}{l}\text { Statements (My reason for } \\
\text { selecting the university in } \\
\text { which I study) }\end{array}$ & Sex & Average & $\begin{array}{c}\text { Sig 2 (tailed) } \\
\text { Level of significance }\end{array}$ \\
\hline $\begin{array}{l}\text { Guidance of my prep/high } \\
\text { school teachers }\end{array}$ & Male & 3.78 & 0.02 \\
\hline Academicians in a certain & Male & 3.56 & 0.03 \\
university. & Female & 3.87 & \\
\hline
\end{tabular}


Table 7 shows the relationship between the size of the city in which students receive education and their level of satisfaction. According to the model summary table, $42 \%$ of students' satisfaction is related to the size of the city in which they study. It is understood, therefore, that the satisfaction level of those students who study in a metropolis is higher.

Table 7: The Regression Analysis Showing the Relationship between the Location of a School and the Satisfaction Level of Students

Model Summary

\begin{tabular}{|c|c|c|c|c|}
\hline Model & $\mathbf{R}$ & R Square & Adjusted R Square & Std. Error of the Estimate \\
\hline 1 & $.209 a$ & 0.44 & 0.42 & 1.137 \\
\hline
\end{tabular}

The value on the significance column of the ANOVA table reveals that the relationship between level of satisfaction and city size is statistically significant at $p<0.01$. Formulating the relationship in the table, we get;

$F(1.905)=22.730 ; p<0.01$

ANOVA $^{\text {b }}$

\begin{tabular}{|cl|c|c|c|c|c|}
\hline Model & & Sum of Squares & df & Mean Square & F & Sig. \\
\hline \multirow{2}{*}{1} & Regression & 29.366 & 1 & 29.366 & 22.730 & $.000^{\text {a }}$ \\
& Residual & 643.392 & 498 & 1.292 & & \\
& Total & 672.758 & 499 & & & \\
\hline
\end{tabular}

a. Predictors: (Constant), School Location

b. Dependent Variable: Satisfaction Level

The coefficients table on the other hand gives the regression coefficients used for the regression equation and their levels of significance. In our example, the coefficient of the variable of the size of the school location is 0.372 , and the constant value of the equation is 1.905 . When we place these values in the equation of $Y=b X+a$, we get the equation $Y=0.372 X+$ 1.905. This equation shows the influence of the size of the university location on student satisfaction.

\begin{tabular}{|c|c|c|c|c|c|c|}
\hline \multicolumn{7}{|c|}{ Coefficients $^{a}$} \\
\hline \multirow[t]{2}{*}{ Model } & & \multicolumn{2}{|c|}{ Unstandardized Coefficients } & $\begin{array}{c}\text { Standardized } \\
\text { Coefficients }\end{array}$ & \multirow[t]{2}{*}{$t$} & \multirow[t]{2}{*}{ Sig. } \\
\hline & & B & Std. Error & Beta & & \\
\hline \multirow{2}{*}{1} & (Constant) & 1.905 & .130 & & 14.602 & .000 \\
\hline & Location & .372 & .078 & .209 & 4.768 & .000 \\
\hline
\end{tabular}

a. Dependent Variable: Satisfaction Level

The relationship of the satisfaction levels of students with two different variables is examined in Table 8. The first of these variables is the life quality of the location and the other is image. In the table, the relationship between the satisfaction of students and city image, on the one hand, and the influence of urban life quality on student satisfaction, on the other hand, were analysed.

According to the correlation analysis, a slightly significant positive relationship exists between the level of satisfaction of students and the image and life quality of the city in which a university is located. If a city has a high quality of life and a good image, the satisfaction level of students regarding their university increases. This result that emerges when Tables 3 and 4 are taken together supports the assumption that there is a relationship between city image and university selections. Students prefer cities with a high quality of life and a good image and, consequently, their levels of satisfaction increase during their university lives. 
Table 8: The Correlation Analysis Showing the Relationship between the City Image of a University and the Satisfaction Level of Students

\begin{tabular}{|c|c|c|c|c|}
\hline & & $\begin{array}{l}\text { Level of Satisfaction } \\
\text { with School }\end{array}$ & $\begin{array}{l}\text { Life Quality of } \\
\text { City }\end{array}$ & City Image \\
\hline $\begin{array}{l}\text { Level of Satisfaction with } \\
\text { School }\end{array}$ & $\begin{array}{c}\text { Pearson Correlation } \\
\text { Sig. (2-tailed) } \\
\text { N }\end{array}$ & $\begin{array}{c}1 \\
500\end{array}$ & $\begin{array}{l}.415^{* *} \\
.000 \\
500\end{array}$ & $\begin{array}{l}.423^{* *} \\
.000 \\
500\end{array}$ \\
\hline
\end{tabular}

**. Correlation is significant at the 0.01 level (2-tailed).

\section{CONCLUSION}

The university entrance exam is extremely important for millions of students because this exam determines what kind of a life students will have in the future. Therefore, the department and school selections that students make become very decisive for their academic and social lives. The fact that many universities have been opened in recent years puts a strain on students regarding their preferences and cause them to remain hesitant among different choices. This situation has also led to the emergence of competition among universities. Opening of numerous departments, presence of vocational high schools in many districts, and spreading of private universities have resulted in an excess supply of quotas in universities. Associate degree programs in many places have been closed because of a lack of students. In some universities, however, none of the departments are closed and, in fact, they face an increasing number of student demand each year. The current study analysed the influence the location of a school on the university selections of students. An answer was sought for the question regarding how the image, size, cultural/social opportunities and economic development level of the area where a university is located influence the preferences of students. According to the findings of the study;

When making their university selections, students primarily choose those schools which are in a close distance to where they live. As a result of increasing competition, many schools have begun to acquire students from their own region. Factors like natural and historical attractions and social environment also shape the selections of students. When making these selections, students consult with those around them such as their friends, and thus they obtain the first information about a certain school from them. It follows based on this finding that especially those schools that suffer a lack of students would be able to fill their quota by satisfying their existing students.

The point that university candidates consider the most when they make selections after the exam is the city in which a university is situated. A favourable city image and a high quality of life will influence their educational life. It is known that those students who study in developed touristy locations with diverse social opportunities become more satisfied with their universities. Thus, city image, which involves all these factors regarding a city, is extremely important for the school selections of students.

Academic criteria like the educational quality in a school, presence of certain academicians and scientific publications are not among the primary points that students consider when they make their school selections. Male students care for the presence of certain academicians in universities and act based on the guidance of their prep school teachers at a higher extent when compared with female students.

It is seen when the findings of the study are assessed in general that students make their university selections primarily based on the city in which universities are located. Proximity of a school to where they live and factors shaping the image of a city such as sociality and cultural/natural richness also become influential in this preference. Those students who act according to city images become happier during their educational lives, and their level of satisfaction with their university tends to increase. Students also consult with their friends, in particular, when obtaining information about certain schools. If universities do not desire to suffer unfilled quota in the future, therefore, they should care more for their existing students. Besides, as the occupancy rate in a university is related to city image, activities that can be taken by the local governors of a city also turn out to be very important. Carrying out image studies, attaching importance to public relations, increasing social opportunities and creation of an urban life which is suitable for students for the purpose of enhancing a city's image are critically important for development of universities and the cities in which they are located. In order to 
actualise this, it will be beneficial in terms of the development of cities and universities to work with specialists who have experience in brand city activities.

\section{REFERENCES}

Avraham, E. (2004). Media Strategies for Improving an Unfavorable City Image. Cities, 21(6), 471-479.

Bakan, Ö. (2008). Kurumsal Kimlik and İmaj. Ed. A. Kalender and M. Fidan, Halkla İlişkiler. Konya: Tablet Yayınları.

Beerli, A. and Martin, J. D. (2004). Factors Influencing Destination Image. Annals of Tourism Research, 31(3), 657-681.

Demirel, M. (2014). Burdur Kent İmajı: Mehmet Akif Ersoy Üniversitesi Öğrencileri Üzerine Bir Alan Araştırması, Mehmet Akif Ersoy Sosyal Biliminler Enstitüsü Dergisi, 6(10), 230-241.

Dumbraveanu, D. (2010). Place Branding: A Challenging Process for Bucharest The Capital City of Romania. Human Geographies, Journal of Studies and Research in Human Geography, 4(2), 53-62.

Drewes, T. and Michael, C. (2006). How Do Students Choose a Unıversıty: An Analysis of Applications to Universities in Ontario, Research in Higher Education, 47(7), 781-800.

Engez, A. (2007). Küreselleşme Sürecinde Kentlerin İmaj ve Kimlikleri: Karşılaştırmalı İstanbul Örneği, Marmara Üniversitesi Sosyal Bilimler Enstitüsü İletişim Bilimleri ABD Halkla İlişkiler BD. Yüksek Lisans Tezi, İstanbul.

Gecikli, F. (2012). Şehir İmajı Amasya Şehri Üzerine Bir Uygulama, Ankara: Fenomen Yayınları.

Giritlioğlu, İ. and Avcıkurt, C. (2010). Şehirlerin Turistik Bir Ürün Olarak Pazarlanması, Örnek Şehirler and Turkey'deki Şehirler Üzerine Öneriler Derlemeden Oluşmuş Bir Uygulama, Adıyaman Üniversitesi Sosyal Bilimler Enstitüsü Dergisi, 3(4), 74-89.

Özdamar, K. (1999). SPSS ile Biyoistatistik. Eskişehir: Kaan Kitabevi.

Özdemir, Ş. and Karaca, Y. (2009). Kent Markası and Marka İmajının Ölçümü: Afyonkarahisar Kenti İmajı Üzerine Bir Araştırma. Afyon Kocatepe Üniversitesi i.i..B.F. Dergisi, 11(2), 113-134.

Paşalı T., N. (2012). Mersin'in Kent Olma Sürecinde Liman ve Serbest Bölgeye illişkin İnternet Pazarlaması Uygulamalarının Rolü. AJIT-e: Online Academic Journal of Information Tecnology, 3(6), 67-76.

Rainisto, S. K. (2003). Success Factors of Place Marketing: A .Study of Place Marketing Practies in Nothern Europe and the United States. (Yayımlanmamış Doktora Tezi). Helsinki Univercity of Technology Institute of Strateggy and International Business.

Sevindi, N. (2003). Kent ve Kültür. İstanbul: Alfa Yayınları.

Shah, M. and Nair, C.S. (2010). Enrolling in Higher Education: The Perceptions of Stakeholders. Journal of Institutional Research, 15(1), 915.

Uçkaç, L. (2006). Kentsel Tasarımın Kent Kimliği Üzerine Etkileri: Keçiören Örneği, Ankara Üniversitesi Fen Bilimleri Enstitüsü Peyzaj Mimarlığı Anabilim Dalı. Yüksek Lisans Tezi. Ankara.

Ünlü A. (1991). Çevresele Kalite, Algı ve Kentsel Tasarım. 1.Kentsel Tasarım ve Uygulamalar Sempozyumu, 328.

Yuan, L. and Chong, C. (2007). The Effect of Festivals and Special Events on City İmage Desingn. Front Archit. Civ. Eng. China, 1(2), $255-259$.

http://www.haberturk.com/gundem/haber/1287736-en-gozde-universitelerde-bile-bos-kontenjan-var

http://www.sinavtakvim.com/node/495

https://tr.wikipedia.org/wiki/Turkey\%27deki_üniversiteler_listesi 